\title{
Changes in the root proteome of Triticosecale grains germinating under osmotic stress
}

\author{
Joanna Grębosz • Anna Badowiec • Stanisław Weidner
}

Received: 1 November 2013/Revised: 13 November 2013/Accepted: 2 December 2013/Published online: 15 December 2013

(C) The Author(s) 2013. This article is published with open access at Springerlink.com

\begin{abstract}
Osmotic stress causes many adverse symptoms in plants, which include, for example, growth limitation and decrease or even absence of yield. Proteomic analyses of plant responses to stressors could lead to the introduction of crops with high resistance to osmotic stress. Such plants would be characterized by high yield even under unfavorable environmental conditions. In this article we describe changes in the protein profiles occurring in response to mild and moderate osmotic stress in triticale roots. Analysis of the protein profiles of these roots showed an increased abundance of 14 and a decreased abundance of 11 proteins under mild osmotic stress conditions while a moderate osmotic stress caused an increased abundance of 18 and a decreased abundance of 33 proteins. Twenty-five proteins, whose quantity altered under stress were identified using MALDI-TOF mass spectrometry. The identified proteins were classified into the categories of proteins associated with: defense mechanisms, metabolism, transcription, cell structure, protein synthesis, transport and signal transduction. The functions of identified proteins were discussed in relation to osmotic stress. Some of the identified proteins may be responsible for the adaptation of plants to adverse conditions.
\end{abstract}

Keywords Proteomics - Triticale - Osmotic stress . Roots

Communicated by M. Hajduch.

J. Grębosz $(\bowtie) \cdot$ A. Badowiec $\cdot$ S. Weidner

Department of Biochemistry, University of Warmia and Mazury in Olsztyn, Oczapowskiego Street 1A, 10-719 Olsztyn, Poland

e-mail: grebosz.joanna@gmail.com

$\begin{array}{ll}\begin{array}{l}\text { Abbreviations } \\ \text { 2-DE }\end{array} & \begin{array}{l}\text { Two-dimensional electrophoresis } \\ \text { Abscisic acid }\end{array} \\ \text { ANA } & \text { Analysis of variance } \\ \text { CBB } & \text { Coomassie Brilliant Blue } \\ \text { HSP } & \text { Heat shock protein } \\ \text { IPG } & \text { Immobilized pH gradient } \\ \text { MALDI-TOF MS } & \begin{array}{l}\text { Matrix-assisted laser desorption/ } \\ \text { ionization time of flight mass } \\ \end{array} \\ \text { spectrometry } \\ \text { NCBI } & \text { National Center for Biotechnology } \\ & \text { Information } \\ \text { PEG } & \text { Polyethylene glycol } \\ \text { PMF } & \text { Peptide mass fingerprinting } \\ \text { ROS } & \text { Reactive oxygen species } \\ \text { USF } & \text { Upstream transcription factor } \\ \text { yeiA } & \text { Dihydropyrimidine dehydrogenase }\end{array}$

Introduction

Triticale is a cereal, which has been obtained artificially by cross-fertilization of rye and wheat. Through this crossing breeders obtained a cereal with higher yield than rye and higher resistance to stress than wheat (Tohver et al. 2005). Because of the high content of exogenous amino acids (mainly lysine) in grains, triticale constitutes a valuable crop plant used for animal nutrition (Jasińska and Kotecki 2003; Rakha et al. 2011). Triticale, like other crops, is exposed to many adverse environmental factors during their life. One of the most commonly occurring abiotic stressors is osmotic stress (Yokoi et al. 2002; Rao et al. 2006). Osmotic stress may be a result of diverse abiotic 
factors such as drought, salinity, cold, polyethylene glycol, mannitol or sorbitol (Verslues et al. 1998; Munnik and Meijer 2001; Legocka and Kluk 2005). Osmotic stress causes many adverse symptoms, which include, among others: plant wilting, impaired growth and development, lower yield or even its absence. Other negative effects of osmotic stress include disorders in such physiological reactions as photosynthesis and formation of the reactive oxygen species (ROS) which lead to oxidation of proteins, amino and nucleic acids, lipid peroxidation, damage and even cell death (Reddy et al. 2004; Sobhanian et al. 2011). Osmotic stress also causes an ion homeostasis disorder and a reduction of chlorophyll and carotene content (Slama et al. 2007; Quados 2010; Sobhanian et al. 2011).

Osmotic stress affects up to $23 \%$ of all arable land (Rao et al. 2006). Due to the increasing demand for food production, researchers have focused on the mechanisms of plant adaptation to water deficit. The aim of the molecular analyses is to facilitate selection of plants with higher adaptation to the conditions of water stress or to introduce new cultivars by using genetic engineering or traditional breeding techniques (Yokoi et al. 2002; Tamura et al. 2003; Rao et al. 2006). The plants' acclimation is related to the changes in gene expression and composition of the proteome and metabolome (Kosová et al. 2011; Swigonska and Weidner 2013). Proteome studies allow the examination of the actual products of gene expression and post-translational modifications of proteins in plants tissues (Jiang et al. 2007). The influence of salt or osmotic stress on the alterations in proteome was examined in tobacco (Dani et al. 2005) and rice leaves (Salekdeh et al. 2002). However, there are still only a few studies focused on the triticale proteome. In this study we used two-dimensional electrophoresis (2-DE) coupled with matrix-assisted laser desorption/ionization time of flight mass spectrometry (MALDI-TOF MS) to analyze the changes in protein composition of the roots of triticale grains germinating under osmotic stress. The aim of this experiment was to broaden the knowledge of the molecular responses of triticale to osmotic stress.

\section{Materials and methods}

Plant material and germination conditions

In these experiments, seeds of winter triticale variety 'Fredro' were used. The seeds were obtained from DANKO, The Plant Breeding Department in Choryń. The grains were collected in 2011 and their ability to germinate was determined to be $96 \%$. Triticale seeds were sterilized with $0.5 \% \mathrm{NaClO}$ solution for $10 \mathrm{~min}$ and washed thoroughly with tap and distilled water. Afterwards, about 120 seeds were placed on Whatman filter paper (Maidstone, Kent, England) moistened with distilled water (control-C) or with a solution of polyethylene glycol (PEG 8000) at concentrations lowering the water potential to $-0.2 \mathrm{MPa}-$ mild osmotic stress (S sample) and to $-0.5 \mathrm{MPa}-$ moderate osmotic stress (SS sample). The rolled sheets of tissue-paper with grains were placed in $250 \mathrm{ml}$ glass cylinders. Approximately $30 \mathrm{ml}$ of distilled water or a PEG solution was dispensed into the cylinders. The seeds were germinated in the dark at $21^{\circ} \mathrm{C}$ for $72 \mathrm{~h}$. The root length in all samples was measured after 24,48 and $72 \mathrm{~h}$ of germination. After $72 \mathrm{~h}$, the roots were cut, weighed, frozen in liquid nitrogen and stored at $-80{ }^{\circ} \mathrm{C}$ for further analysis. The experiment was conducted in three independent biological replicates.

\section{Protein extraction and purification}

The extraction of proteins was carried out according to the procedure proposed by Gallardo et al. (2002). About $1 \mathrm{~g}$ of frozen root tissue was carefully pulverized in mortars cooled with liquid nitrogen and the material transferred to Eppendorf tubes with a suitable amount $(20 \mu \mathrm{l} / \mathrm{mg}$ dry weight of tissue) of lysis buffer containing: $7 \mathrm{M}$ urea; $2 \mathrm{M}$ thiourea; $4 \%$ CHAPS; $40 \mathrm{mM}$ dithiothreitol; $2 \%$ ampholytes pH 3-11; 60 U/ml DNase I; 5.8 Kunitz/ml RNase A; 1 pill/10 ml protease inhibitor Cocktail Tablets cOmplete Mini (Roche). The samples were shaken on ice for $45 \mathrm{~min}$ and then centrifuged at $18,000 \times g$ for $10 \mathrm{~min}$ at $4{ }^{\circ} \mathrm{C}$. The supernatant was transferred to a new tube and re-centrifuged. Centrifugation was repeated until a clean solution containing the protein extract was obtained. These protein extracts were purified using Ready Prep ${ }^{\mathrm{TM}}$ 2-D Cleanup Kit (Bio-Rad), according to the manufacturer's instructions. The protein content was measured using $2 \mathrm{D}$ Quant Kit (Amersham Biosciences).

\section{2-DE}

The procedure described by Görg et al. (2004) was used for protein isoelectrofocusing (first dimension). The protein pellets were dissolved in rehydration buffer (7 M urea; $2 \mathrm{M}$ thiourea; $2 \%$ CHAPS; $0.5 \%$ ampholytes $\mathrm{pH} 3-11 ; 0.002 \%$ bromophenol blue; $80 \mathrm{mM}$ dithiothreitol). $450 \mu \mathrm{l}$ of the protein solution containing $400 \mu \mathrm{g}$ of proteins was loaded onto a 24-cm IPG gel strip with a non-linear immobilized $\mathrm{pH}$ gradient (3-11) (Immobiline ${ }^{\mathrm{TM}}$ DryStrip, GE Healthcare) and covered with $1 \mathrm{ml}$ of mineral oil Dry Strip Cover Fluid (Amersham Biosciences). Isoelectrofocusing was performed in Ettan IPGphor 3 (GE Healthcare) apparatus. Prior to the actual separation, the rehydration process was carried out at $20{ }^{\circ} \mathrm{C}(30 \mathrm{~V} / 12 \mathrm{~h})$. The parameters of other stages of separation were as follows: $500 \mathrm{~V} / 1 \mathrm{~h}, 1,000 \mathrm{~V} / 1 \mathrm{~h}, 8,000 \mathrm{~V} /$ 
$3 \mathrm{~h}, 8,000 \mathrm{~V} / 3 \mathrm{~h} 45 \mathrm{~min}$. After isoelectrofocusing, the strips were placed in the equilibration buffer containing $6 \mathrm{M}$ urea; 75 mM Tris- $\mathrm{HCl}$ pH 8.8; $29.3 \%$ glycerol; $2 \%$ sodium dodecyl sulfate; $0.002 \%$ bromophenol blue with $100 \mathrm{mg}$ dithiothreitol/10 $\mathrm{ml}$ buffer and were rocked gently for $15 \mathrm{~min}$. The buffer was then decanted and replaced with the same amount of the equilibration solution containing $250 \mathrm{mg} / 10 \mathrm{ml}$ iodoacetamide, instead of dithiothreitol and stirred for another $15 \mathrm{~min}$. These IPG strips containing proteins separated according to their isoelectric point were placed onto a $12.5 \%$ polyacrylamide denaturing gel. SDSPAGE (second dimension) was performed according to O'Farrel (1975), using a buffer system described by Laemmli (1970). The gels were placed in Ettan DALT six (GE Healthcare) apparatus and the proteins were separated at $25^{\circ} \mathrm{C}$ for $30 \mathrm{~min}$ at $2 \mathrm{~W} / \mathrm{gel}$ and then for $3.5 \mathrm{~h}$ at $17 \mathrm{~W} / \mathrm{gel}$. The low-range SDS-PAGE (Bio-Rad) marker was used for the establishment of molecular weight of the proteins. After electrophoresis, gels were incubated for $30 \mathrm{~min}$ in the fixing solution (40\% methanol; $10 \%$ acetic acid). In order to visualize proteins on the gels, the colloidal solution of Coomassie Brilliant Blue (CBB) G-250 staining was applied, according to the methodology described by Neuhoff et al. (1988).

\section{Analysis of 2-DE gels}

For the analysis of polyacrylamide gels, Image Scanner III (GE Healthcare) and the Image Master ${ }^{\mathrm{TM}}$ 2D Platinum 6.0 (GE Healthcare) program were used. In order to determine quantitative changes between proteins, the gels were analyzed using the relative volume (\%vol) of the detected proteins. The proteins, whose expression under stress changed significantly $(p<0.05)$ of at least 1.5 -fold, were excised from the gels and identified by MALDI-TOF MS (Bruker Daltonik). The statistical analysis was performed using Statistica 10.0 software (StatSoft), GraphPad Prism 6 (GraphPad) and Microsoft Office Excel 2007 (Microsoft). One-way ANOVA (analysis of variance) and nonparametric Kruskal-Wallis tests were used to assess the relevance of the obtained results.

\section{MALDI-TOF mass spectrometry}

Proteins, whose expression increased or decreased at least 1.5-fold, compared with the control, were excised from the gels with a sterile scalpel blade and placed in Eppendorf tubes. Isolated proteins were destained, dehydrated and digested overnight (using $10 \mu \mathrm{l}$ of the modified trypsin solution at a concentration of $20 \mathrm{ng} / \mu \mathrm{l}$ ) following the procedure described by Shevchenko et al. (1996). In order to extract the peptides from the gel, $0.5 \mu \mathrm{l}$ of acetonitrile was added to the solution with gel fragments and the tubes were placed in an ultrasonic bath for $5 \mathrm{~min}$. Then, $0.5 \mu \mathrm{l}$ of the peptide solution and the $0.5 \mu \mathrm{l}$ of matrix (supersaturated solution of $\alpha$-cyano-4-hydroxycinnamic acid in $50 \%$ acetonitrile and $0.1 \%$ trifluoroacetic acid) were applied on the Target Plate (Bruker Daltonik) and left to crystallize. Peptide mixtures were analyzed using the MALDI-TOF mass spectrometer (Bruker Daltonik). The $\mathrm{m} / \mathrm{z}$ (mass to charge) ratio of the peptides appearing in mass spectra was used for protein identification by peptide mass fingerprinting (PMF) using the MASCOT program (Matrix Science) and databases of protein sequences: NCBI (National Center of Biotechnology Information) and SwissProt. The databases were screened for Viridiplantae (green plants) with the following parameters: 0.2 Da mass tolerance, one missed cleavage, carbamidomethylation of cysteines as fixed modifications and oxidation of methionine as variable modifications. The division of the identified proteins into groups (according to their functions) was based on the information obtained through bioinformatics tools Quick Go and UniProt and the classification method given by Bevan et al. (1998).

\section{Results}

Osmotic stress had a significant influence on elongation and alterations in protein profiles of triticale roots. The inhibitory effect of osmotic stress on root growth is shown in Fig. 1. The lengths of the roots grown for $24 \mathrm{~h}$ were 1.43 $( \pm 0.52) \mathrm{mm}$ in the control sample $(\mathrm{C})$ and $1( \pm 0) \mathrm{mm}$ in the stress samples ( $\mathrm{S}$ and $\mathrm{SS}$ ). After $48 \mathrm{~h}$ of germination the root length reached $18.21( \pm 7.13) \mathrm{mm}(\mathrm{C}), 11.9$ $( \pm 4.02) \mathrm{mm}(\mathrm{S})$, and $6.31( \pm 2.78) \mathrm{mm}(\mathrm{SS})$. The root length after $72 \mathrm{~h}$ of germination was $47.64( \pm 20.46) \mathrm{mm}$ (C), $33.36( \pm 14.77) \mathrm{mm}(\mathrm{S})$ and $20.71( \pm 9.26) \mathrm{mm}(\mathrm{SS})$.

Analysis (qualitative and quantitative) of the proteome included separation of the extracted proteins by 2-DE, spot analysis in Image Master ${ }^{\mathrm{TM}}$ 2D Platinum 6.0 and identification of the selected proteins (differing at least 1.5-fold with $p<0.05$ ) using MALDI-TOF MS and MASCOT program. The electrophoregram analysis resulted in the detection of 1,698 proteins found both in the control (C) and the sample treated with a mild osmotic stress (S) and 1,870 proteins common to the control (C) and the sample under moderate osmotic stress (SS). Image analysis showed a significant quantitative increase (at least 1.5 -fold) of 14 and a decrease of 11 proteins under mild osmotic stress conditions while a moderate osmotic stress caused an increase in abundance of 18 and a decrease in 33 proteins. Twenty-five of the 66 proteins which demonstrated changes in expression under conditions of osmotic stress were identified using MALDI-TOF mass spectrometry. The identified proteins are marked on the gel images in Fig. 2. 

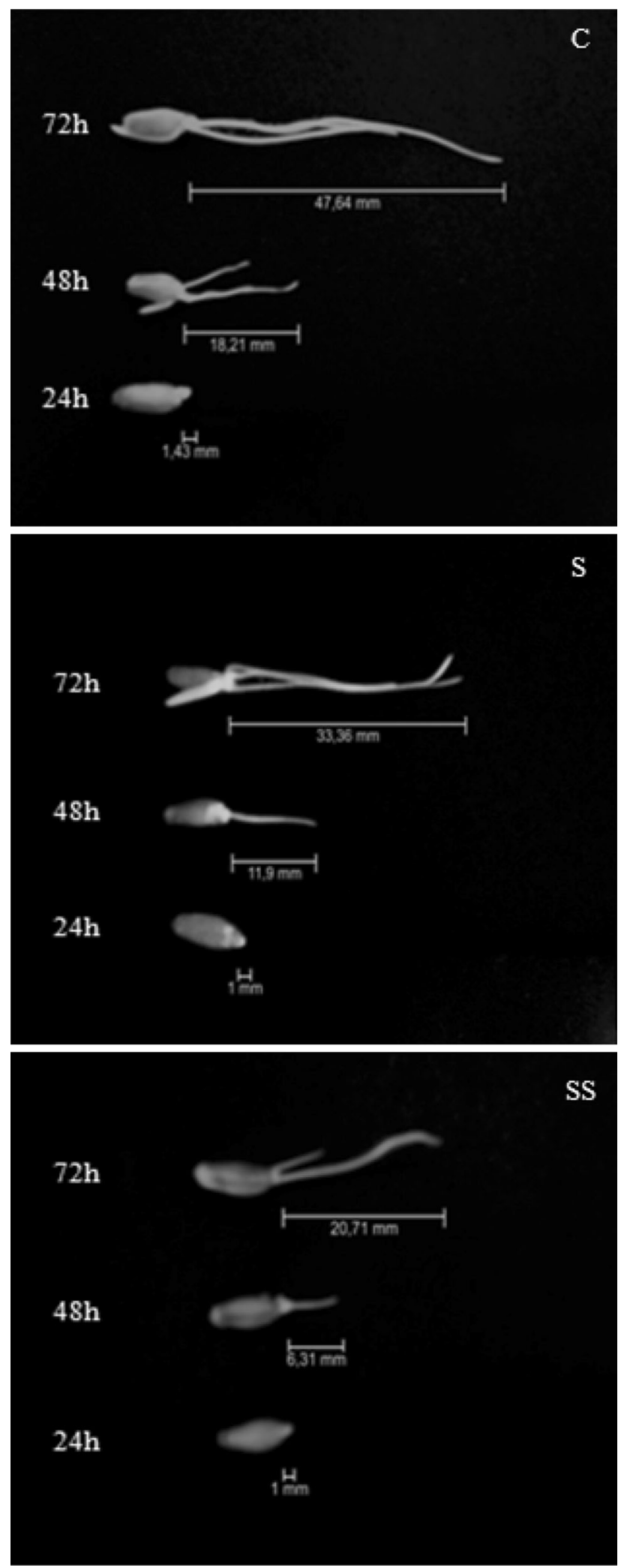

The rest of the selected proteins were not identified because of an insufficient amount of the proteins in the gel fragments or lack of the appropriate information (for triticale
Fig. 1 Growth of triticale roots under different water stress conditions. The photographs show triticale grains after 24,48 and $72 \mathrm{~h}$ of germination under: optimal conditions- $C$, mild osmotic stress conditions $(-0.2 \mathrm{MPa})-S$ and moderate osmotic stress conditions $(-0.5 \mathrm{MPa})-S S$. The photographs also indicate the average root length of germinating grains

proteins) in the databases. Among the identified proteins, 9 showed an increased and 16 a decreased abundance as a result of 72-h osmotic stress treatment (compared with the control sample, C).

In response to both moderate and mild osmotic stress, the expression of proteins such as peroxidase 66 (spot 2), a transcription factor, protein USF (spot 19), DEAD-box ATP-dependent RNA helicase 41 (spot 20), putative phospholipase D $\alpha 1$ precursor (spot 25) increased. Mild osmotic stress caused an increase in the expression of proteins such as $\alpha$-1,4-glucan-protein synthase UDPforming (spot 9), predicted protein (spot 22) (homologous to the protein from Hordeum vulgare subsp. vulgare). Increased expression under moderate osmotic stress elevated levels of small heat shock proteins-sHSP22 (spot 6), hypothetical protein TRIUR3_26221 (spot 14), and 30S ribosomal protein S3 (spot 23). Decreases in the expression in both mild and moderate osmotic stress were observed for peroxidase (spot 5) and hypothetical protein F775_28997 (spot 15). Decreased expression only under moderate osmotic stress showed the following proteins: $\beta$-glucosidase (spot 10), V-type protein ATPase subunit B1 (spot 24 ), actin (spot 21), hypothetical protein OsI_13043 (spot 16 ), peroxidase precursor (spot 1), glucan endo-1,3- $\beta$-glucosidase (spot 8), tubulin (spot 22), endoglucanase 10 (spot 12), HSP70 (spot 7), hypothetical protein TRIUR3_12251 (spot 17), $S$-adenosylmethionine synthetase (spot 13), two isoforms of ascorbate peroxidase (spot 3 and 4) and putative protein yeiA (spot 11).

The identified proteins were classified based on their biological functions (Fig. 3). The largest group of the identified proteins $(32 \%)$ whose expression was affected by the osmotic stress, were classified into the group of proteins participating in defense mechanisms. Proteins included in this category were peroxidase precursor (spot 1), peroxidase 66 (spot 2), peroxidase (spot 5), ascorbate peroxidase (spot 3 and 4), sHSP22 (spot 6), HSP70 (spot 7 ), and glucan endo-1,3-beta-glucosidase (spot 8). Another group of proteins (20\% of the identified polypeptides) were the proteins involved in metabolism. These include $\alpha$ 1,4-glucan-protein synthase UDP-forming ( spot 9), $\beta$-glucosidase (spot 10), putative protein yeiA (spot 11), endoglucanase 10 (spot 12 ) and $S$-adenosylmethionine synthetase (spot 13). Two classes of proteins, performing functions in the process of transcription (USF proteinspot 19, DEAD-box RNA helicase 41-spot 20) and 
forming cellular structures (actin-spot 21, tubulin-spot 22 ), constituted $8 \%$ of the identified proteins and exhibited a much lower abundance in stress conditions. The groups with the smallest number of classified proteins were the classes of proteins involved in protein synthesis (30S
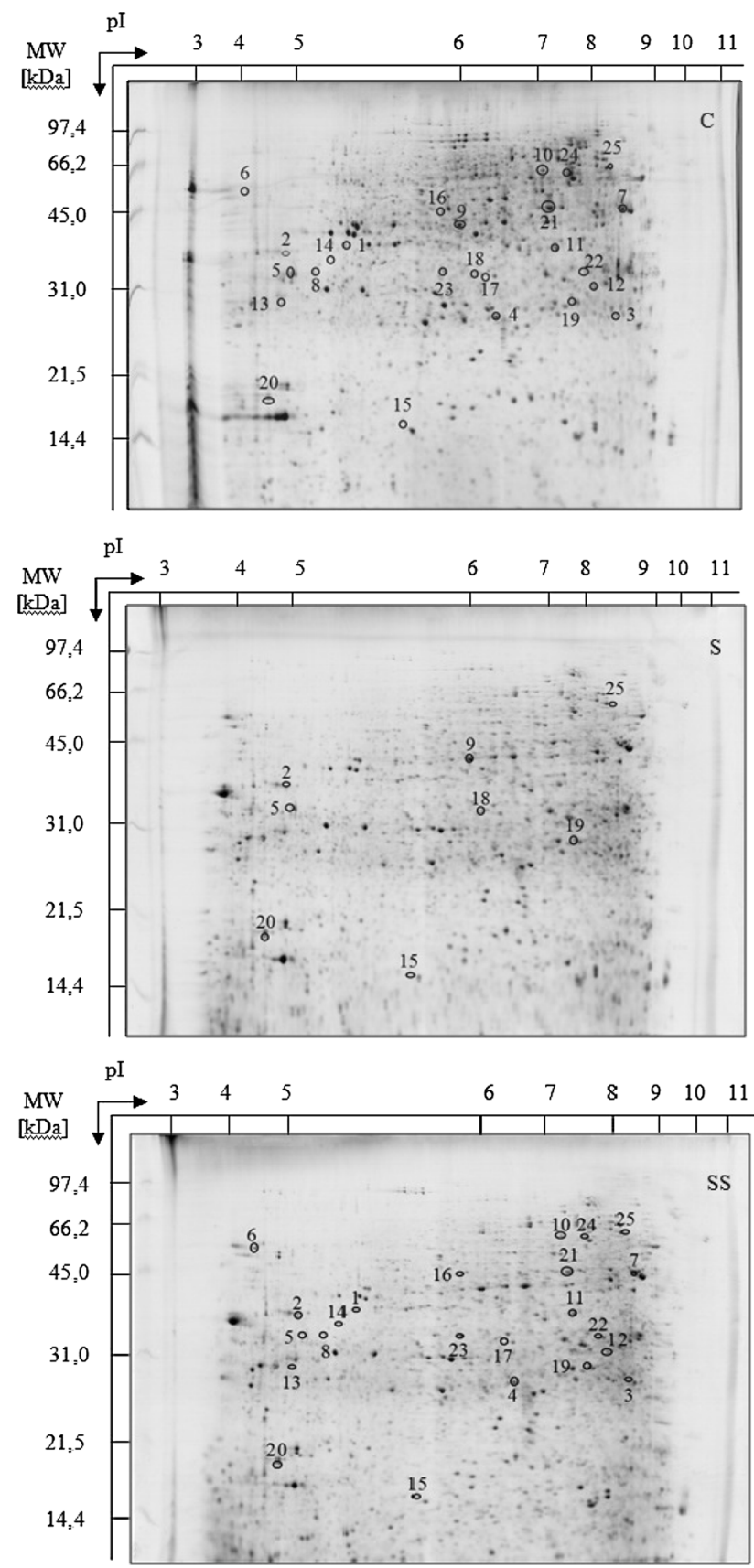

Fig. 2 Electophoregrams obtained from the separation of triticale root proteomes by 2-DE. Seeds were germinated for $72 \mathrm{~h}$ under optimal $(C)$, mild $(S)$ and moderate osmotic stress $(S S)$ conditions. The proteins whose expression changed under stress conditions at least 1.5-fold compared with control $(C)$ are indicated with the circles. On the left side of the gels are shown the molecular weights (MW) and at the top, the isoelectric points of the proteins $(\mathrm{p} I)$ ribosomal protein $\mathrm{S} 3$ - spot 23), molecule transport (Vtype ATPase subunit B1-spot 24) and signal transduction (putative phospholipase D $\alpha 1$ precursor-spot 25). Five proteins $(20 \%)$ were unclassified because of their unknown function (hypothetical proteins: spots 14, 15, 16, 17, 18). The characteristics of the identified proteins assigned to the separate groups are shown in Table 1.

\section{Discussion}

Analysis of the average length of the longest triticale root indicated that significant growth inhibition was elicited by osmotic stress. Similar results were obtained by other researchers analyzing shoot elongation in bent grass $(\mathrm{Xu}$ and Huang 2010). It was observed that higher concentrations of PEG solutions result in more significant inhibition of root elongation. A similar relationship was also noticed in another study (El Midaoui et al. 2003).

Comparative analysis of the protein profiles of triticale roots helped to indicate proteins with expression altered by the osmotic stress. The selected proteins, whose quantity increased or decreased at least 1.5-fold, were identified by mass spectrometry (MALDI-TOF) and classified into such categories as defense mechanisms, metabolism, cell structure, protein synthesis, transport and signal transduction.

The group of proteins related to defense mechanisms is represented by peroxidases. They are involved, among other processes, in the regulation of reactive oxygen species (ROS), which are formed in excess as a result of osmotic stress (Xiong and Zhu 2002; Passardi et al. 2005; Koussevitzky et al. 2008). Our experiment showed various levels of the peroxidase family of proteins. Under moderate osmotic stress there was a decrease in the expression of the following proteins: peroxidase (lactoperoxidase), two isoforms of cytosolic ascorbate peroxidase and peroxidase

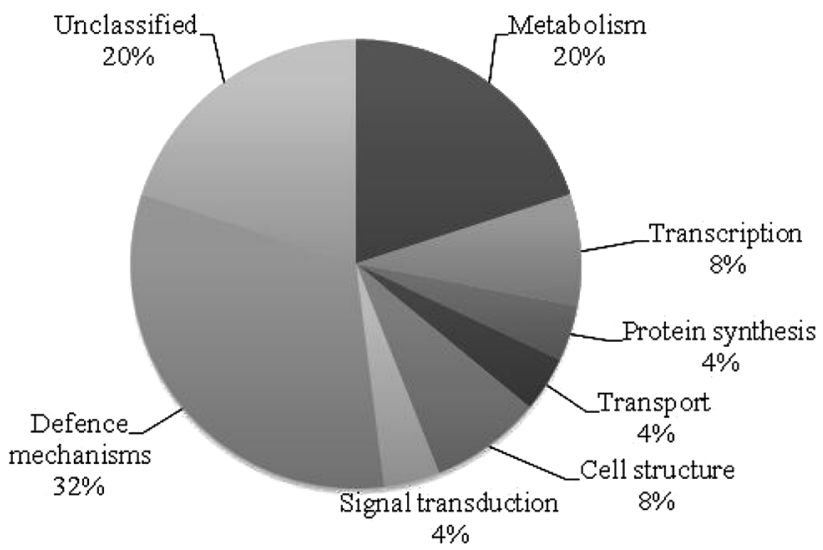

Fig. 3 The functional classification of the identified proteins whose expression altered under osmotic stress 
Table 1 The proteins with altered expression $(1.5$-fold to control at $p<0.05)$ in the roots of triticale grains germinated for $72 \mathrm{~h}$ under mild (S) and moderate (SS) osmotic stress, identified using MALDI-TOF MS

\begin{tabular}{|c|c|c|c|c|c|c|c|c|}
\hline $\mathrm{ID}^{\mathrm{a}}$ & $\begin{array}{l}\text { Accession } \\
\text { number }\end{array}$ & Identified protein (plant species) & Score & $\begin{array}{l}\text { Matched } \\
\text { peptides }\end{array}$ & $\begin{array}{l}\text { Cov. } \\
(\%)^{\mathrm{c}}\end{array}$ & $\begin{array}{l}\text { Theor. pI/MW } \\
(\mathrm{kDa})^{\mathrm{d}}\end{array}$ & $\begin{array}{l}\text { Exp. pI/MW } \\
(\mathrm{kDa})^{\mathrm{e}}\end{array}$ & $\begin{array}{l}\text { Change } \\
\text { in } \mathrm{S} / \mathrm{SS} \mathrm{S}^{\mathrm{f}}\end{array}$ \\
\hline \multicolumn{9}{|c|}{ Defense mechanisms } \\
\hline 1 & gil58334052 & Peroxidase precursor (Triticum aestivum) & 94 & 7 & 29 & $5.58 / 37.00$ & $5.31 / 37.06$ & $-/ 0.55$ \\
\hline 2 & gil474004599 & Peroxidase 66 (Triticum urartu) & 129 & 11 & 35 & $5.85 / 46.23$ & $4.97 / 36.10$ & $1.58 / 2.18$ \\
\hline 3 & APX2_ORYSJ & $\begin{array}{l}\text { L-ascorbate peroxidase } 2 \text {, cytosolic (Oryza sativa } \\
\text { subsp. japonica) }\end{array}$ & 65 & 6 & 37 & $5.21 / 27.22$ & $8.32 / 27.60$ & $-/ 0.66$ \\
\hline 4 & gil3688398 & $\begin{array}{l}\text { Ascorbate peroxidase (Hordeum vulgare subsp. } \\
\text { vulgare) }\end{array}$ & 99 & 10 & 48 & $5.85 / 27.53$ & $6.49 / 26.66$ & $-/ 0.62$ \\
\hline 5 & PER1_WHEAT & Peroxidase (Triticum aestivum) & 70 & 8 & 34 & $8.37 / 32.87$ & $5.02 / 32.87$ & $0.41 / 0.15$ \\
\hline 6 & HS22C_SOYBN & sHSP22, chloroplastic (Glycine max) & 61 & 6 & 31 & $5.47 / 20.58$ & $4.08 / 52.44$ & $-/ 3.91$ \\
\hline 7 & gil357503195 & Heat shock protein (Medicago truncatula) & 100 & 11 & 28 & $5.08 / 71.35$ & $8.46 / 43.94$ & $-/ 0.67$ \\
\hline 8 & gil474044907 & $\begin{array}{l}\text { Glucan endo-1,3-beta-glucosidase GI (Triticum } \\
\text { urartu) }\end{array}$ & 76 & 7 & 39 & $7.70 / 33.04$ & $5.14 / 32.81$ & $-/ 0.63$ \\
\hline \multicolumn{9}{|c|}{ Metabolism } \\
\hline 9 & gil475453336 & $\begin{array}{l}\text { Alpha-1,4-glucan-protein synthase UDP-forming } \\
\text { (Aegilops tauschii) }\end{array}$ & 147 & 20 & 50 & $6.02 / 41.03$ & $6.00 / 40.70$ & $1.59 /-$ \\
\hline 10 & gil475505622 & Beta-glucosidase, chloroplastic (Aegilops tauschii) & 75 & 7 & 13 & $6.39 / 62.32$ & $5.22 / 34.76$ & $-/ 0.60$ \\
\hline 11 & gil475610606 & Putative protein yeiA (Aegilops tauschii) & 75 & 7 & 22 & $5.99 / 46.76$ & $7.50 / 36.28$ & $-/ 0.57$ \\
\hline 12 & GUN10_ARATH & Endoglucanase 10 (Arabidopsis thaliana) & 64 & 7 & 26 & $6.77 / 58.12$ & $5.29 / 30.67$ & $-/ 0.46$ \\
\hline 13 & gil115589746 & $\begin{array}{l}\text { S-adenosylmethionine synthetase } 2 \\
\text { (Triticum monococcum) }\end{array}$ & 95 & 7 & 40 & $7.34 / 31.55$ & $4.85 / 28.47$ & $-/ 0.67$ \\
\hline \multicolumn{9}{|c|}{ Unclassified } \\
\hline 14 & gil473965096 & $\begin{array}{l}\text { Hypothetical protein TRIUR3_26221 } \\
\text { (Triticum urartu) }\end{array}$ & 98 & 8 & 42 & $6.78 / 26.93$ & $5.22 / 34.76$ & $-/ 1.60$ \\
\hline 15 & gil475554779 & Hypothetical protein F775_28997 (Aegilops tauschii) & 110 & 9 & 20 & $8.03 / 52.10$ & $5.65 / 36.67$ & $0.43 / 0.59$ \\
\hline 16 & gil326505562 & $\begin{array}{l}\text { Hypothetical protein OsI_13043 (Oryza sativa Indica } \\
\text { Group) }\end{array}$ & 78 & 7 & 32 & $9.90 / 35.22$ & $5.89 / 43.65$ & $-/ 0.49$ \\
\hline 17 & gil474401890 & $\begin{array}{l}\text { Hypothetical protein TRIUR3_12251 (Triticum } \\
\text { urartu) }\end{array}$ & 90 & 9 & 44 & $5.68 / 32.92$ & $6.37 / 31.85$ & $-/ 0.67$ \\
\hline 18 & gil326505562 & Predicted protein (Hordeum vulgare subsp. vulgare) & 151 & 12 & 54 & $6.12 / 34.75$ & $6.21 / 32.28$ & $1.51 /-$ \\
\hline \multicolumn{9}{|c|}{ Transcription } \\
\hline 19 & gil475533294 & Protein USF (Aegilops tauschii) & 80 & 8 & 49 & $5.23 / 24.70$ & $7.79 / 28.45$ & $1.99 / 1.68$ \\
\hline 20 & RH41_ORYSJ & $\begin{array}{l}\text { DEAD-box ATP-dependent RNA helicase } 41 \text { (Oryza } \\
\text { sativa subsp. japonica) }\end{array}$ & 64 & 6 & 14 & $7.14 / 59.92$ & $4.56 / 18.28$ & $1.55 / 1.60$ \\
\hline \multicolumn{9}{|c|}{ Cell structure } \\
\hline 21 & gil6103623 & Actin (Picea rubens) & 132 & 15 & 48 & $5.30 / 41.79$ & $7.39 / 44.19$ & $-/ 0.56$ \\
\hline 22 & TBB4_WHEAT & Tubulin beta-4-chain (Triticum aestivum) & 63 & 8 & 18 & $4.78 / 50.64$ & $7.99 / 32.54$ & $-/ 0.44$ \\
\hline \multicolumn{9}{|c|}{ Protein synthesis } \\
\hline 23 & RR3_PSINU & $\begin{array}{l}\text { 30S ribosomal protein S3, chloroplastic (Psilotum } \\
\text { nudum) }\end{array}$ & 63 & 5 & 32 & $9.70 / 25.81$ & $5.89 / 32.70$ & $-/ 1.72$ \\
\hline \multicolumn{9}{|c|}{ Transport } \\
\hline 24 & VATB1_HORVU & $\begin{array}{l}\text { V-type protein ATPase subunit B } 1 \text { (Hordeum } \\
\text { vulgare) }\end{array}$ & 158 & 14 & 43 & $5.12 / 54.11$ & $7.72 / 57.11$ & $-/ 0.46$ \\
\hline \multicolumn{9}{|c|}{ Signal transduction } \\
\hline 25 & gil209944121 & $\begin{array}{l}\text { Putative phospholipase } \mathrm{D} \alpha 1 \text { precursor (Triticum } \\
\text { monococcum) }\end{array}$ & 82 & 8 & 19 & $5.40 / 62.28$ & $8.33 / 59.64$ & $2.14 / 1.53$ \\
\hline
\end{tabular}

${ }^{a}$ ID of the protein, corresponding to the number in the Fig. 1

${ }^{\mathrm{b}}$ Number of matched peptides

c Sequence coverage (\%)

d Theoretical $\mathrm{p} / \mathrm{MW}$

e Experimental pI/MW

${ }^{\mathrm{f}}$ Fold change in the roots of seeds germinating under mild (S)/moderate (SS) osmotic stress conditions 
precursor. A significant decrease in expression of peroxidase was observed under mild osmotic stress conditions. Reduction of peroxidase accumulation by the action of osmotic stress was observed in other studies (Jiang and Deyholos 2006; Ma et al. 2009; Ge et al. 2012). Decrease in the abundance of this enzyme in the tissues could reduce the adaptability of the plants to stress as evidenced, for example, in the study of Arabidopsis mutants, deprived of the ability to synthesize ascorbate peroxidase (Koussevitzky et al. 2008). Triticale treated with mild and moderate osmotic stress, however, showed an increased expression of peroxidase 66, which indicates some defensive reaction of the plant (combating harmful excess of ROS) to the adverse environmental conditions.

Another protein whose expression significantly decreased in response to moderate osmotic stress was glucan endo-1,3-beta-glucosidase. This enzyme degrades the $\beta$-glucan-component of hemicelluloses which builds cell walls (Huber and Nevins 1981). Glucosidase produced in large quantities during the germination of seeds allows the cleavage of plant's storage substances by hydrolysis of the endosperm cell walls (Leah et al. 1995). Some studies have shown that the increase in the synthesis of beta-glucosidase is associated with a higher plant tolerance to osmotic stress (Budak et al. 2013). This enzyme stimulates tissue growth and adapts the plant to altered environmental conditions by reducing the water potential of the cells (Mohammadi et al. 2007).

Two heat shock proteins, sHSP22 and HSP70, were identified in this work. HSPs play a protective function towards other proteins during various abiotic stresses. HSPs are involved in such processes as protein-protein interactions, protein folding, secretion and transport as well as protection against protein degradation and aggregation (Timperio et al. 2008; Mohammadi et al. 2012b). The quantity of a small HSP (sHSP22) significantly increased in the sample treated with moderate osmotic stress. Small HSPs interact with HSP100/HSP70 and participate in the protection of other proteins (Sarkar et al. 2009). A high tolerance to osmotic stress of plants has been correlated with a production of large amounts of HSPs (Alvim et al. 2001; Mohammadi et al. 2012a). The small HSP identified in the roots of triticale probably prevents unfolding of other proteins and facilitates plant defense against stress. Moderate osmotic stress caused down-regulation of HSP70. A similar trend was also noticed in the studies analyzing the bentgrass leaf proteome under osmotic stress (Xu and Huang 2010) and the pea root proteome under short chilling stress (Badowiec et al. 2013). There were no significant changes in the amount of HSPs in the sample germinated under mild osmotic stress conditions. Decrease in HSP70 expression in the triticale roots suggests, therefore, some disturbances in protein metabolism, perhaps caused by weak plant adaptation to stressful conditions.

$S$-adenosylmethionine synthetase is an enzyme essential for DNA, RNA and protein methylation, biosynthesis of cell wall components and, indirectly, for the synthesis of polyamines and ethylene (Espartero et al. 1994; Grillo and Colombatto 2008). It was revealed that the increased synthesis of polyamines (whose production depends on this synthase) increases tolerance of some plants to the osmotic stress (Wi et al. 2006). The amount of this enzyme significantly decreased in the sample treated with moderate osmotic stress. A similar effect was also reported in other proteomic (Yan et al. 2005; Toorchi et al. 2009; Mohammadi et al. 2012b) and transcriptomic (Espartero et al. 1994) studies. This synthetase is probably involved in the control of gene expression under osmotic stress conditions due to its ability to methylate nucleic acids and, therefore, may constitute an interesting target for genetic engineering of plant resistance to this stress (Mohammadi et al. 2012b).

Under moderate osmotic stress conditions the amount of $\beta$-glucosidase decreased. Beta-glucosidases participate in lignification of the cell walls, $\beta$-glucan catabolism, activation of phytohormones, stimulation of the aromatic compounds synthesis and in other defensive processes (Cairns and Esen 2010). In response to drought stress, $\beta$ glucosidases may increase the amount of abscisic acid (ABA) - an essential signaling factor which is involved in adapting plants to stress conditions (Bargmann and Munnik 2006; Cairns and Esen 2010; Wang et al. 2011). Studies on $\beta$-glucosidase showed its important role in increasing the tolerance of plants to osmotic and drought stress (Hermosa et al. 2011; Wang et al. 2011).

Another identified protein whose expression decreased in triticale roots under moderate osmotic stress was endoglucanase 10, which is capable of degradation of cell wall components and thus involved in cell elongation (Biswas et al. 2006; Geilfus et al. 2011). Studies performed on maize showed that the decrease of cellulases in the leaves may be associated with a lower tolerance to salt stress and inhibition of plant growth (Geilfus et al. 2011).

A putative yeiA protein, also known as dihydropyrimidine dehydrogenase, exhibited a significant decrease in expression under moderate osmotic stress conditions. This enzyme is involved in the reduction of pyrimidines (uracil and thymine) to 5,6-dihydro derivatives (Hidese et al. 2011). Pyrimidine degradation contributes to the production of the substrate ( $\beta$-alanine) for the synthesis of pantothenate, necessary to produce coenzyme A (Zrenner et al. 2009). Pyrimidine catabolism may be a source of nitrogen for the plants (Zrenner et al. 2009). The decrease in yeiA protein expression may be associated with a lower demand for nitrogen caused by the inhibition of growth and reduction of protein synthesis under stress conditions 
(Brosowska-Arendt and Weidner 2011). Increased formation of nitrogen compounds increases the adaptability of plants to salt stress (Mansour 2000). Although the role of yeiA protein has not been so far adequately investigated, it may be assumed that the overexpression of this protein could increase triticale tolerance to osmotic stress by increasing the pool of protective amino acids in tissues.

Another protein whose expression increased under moderate osmotic stress conditions was $\alpha$-1,4-glucan synthase. This enzyme is involved in synthesis of $\alpha$-glucan, found in the plant's primary reserve material-starch (Hochstenbach et al. 1998; Kok-Jacon et al. 2003). It was demonstrated that osmotic stress causes changes in the biosynthesis of starch (Ge et al. 2012). A reduced demand for carbohydrates in cells may be due to the inhibition of triticale growth under osmotic stress (Brosowska-Arendt and Weidner 2011). This synthase also plays an important role in cell wall synthesis and morphogenesis of yeast (Hochstenbach et al. 1998). It is assumed that the protein may also be involved in the synthesis of hemicellulose which is a component of plant cell walls (Dhugga et al. 1997).

The increased expression under the action of both mild and moderate osmotic stress was exhibited also by the USF protein-a DNA-binding upstream transcription factor which participates in the regulation of transcription and cell proliferation inhibition (Ghosh et al. 1997; Qyang et al. 1999). An increased amount of USF protein in triticale roots could, therefore, influence the transcription of other genes.

Also the DEAD-box RNA helicase 41 (ATP-dependent) increased in abundance under the influence of both of the applied osmotic stresses. A similar trend in the expression of DEAD-box helicase was observed in barley tissues in response to salt and osmotic stress (Nakamura et al. 2004) and soybean tissues in response to salt stress (Chung et al. 2009). DEAD-box helicases affect transcription and translation, nearly all the processes related to the metabolism of RNA and ribosome synthesis (Nakamura et al. 2004; Chung et al. 2009). The work of Amin et al. (2012) shows that transgenic rice with overexpression of one of the RNA helicases exhibits an increased yield under stress conditions. Perhaps the helicase identified in our experiment influences the expression of other genes in stressed triticale tissues, responsible for plant resistance to osmotic stress (Vashisht and Tuteja 2006).

One of the cell structure proteins undergoing decreased expression due to the impact of moderate osmotic stress was $\beta$-tubulin. Similar results were also obtained in studies concerning rice stems (Song et al. 2011). As a component of microtubules, $\beta$-tubulin plays a role in cell growth and division as well as in cell wall development (Jost et al. 2004; Libusová et al. 2005). Reduced expression of $\beta$ - tubulin could, therefore, affect the inhibition of triticale root growth in response to osmotic stress. Inhibition of growth in this case could be associated with impaired cell division and cell wall synthesis, arising under the action of stress. The previously reported decline of $\beta$-tubulin amount in plants susceptible to drought indicates the important role of this protein in the processes of plant adaptation to adverse conditions (Mohammadi et al. 2012a).

It was observed that the quantity of another cytoskeleton-associated protein, actin, was reduced under moderate osmotic stress. Similar results were also obtained in the study on Arabidopsis roots (Jiang et al. 2007). Actin is a component of the microfilaments which are involved in transport of organelles as well as in the regulation of cell division and elongation (Liu 2011). A decrease in the expression of both tubulin and actin entails a reduction in cell size which can be one of the mechanisms of plant's adaptation to osmotic stress. Reducing the volume of the cells may in fact facilitate the maintenance of cell homeostasis and turgor (Xu et al. 2010).

A protein whose expression increased under moderate osmotic stress was chloroplast 30S ribosomal protein S3protein associated with translation. Plant roots typically contain proplastids, some of which can be changed into chloroplasts after exposure to light (Oliveira 1982). S3 protein is involved in the synthesis of small ribosomal subunit (30S) and in the repair of DNA damage (Kim et al. 2005). S3 may also function as a transcription factor (Wan et al. 2007). In connection with these functions, this protein may cause an increase in triticale stress tolerance.

Also V-type ATPase subunit B1 undergoes down-regulation under moderate osmotic stress conditions. Similar results were obtained in the roots of wheat seeds germinating under salt stress (Wang et al. 2000). V-type ATPase allows the accumulation of excess ions in the tonoplast, which is one of plant's defense mechanisms in response to salt stress (Wang et al. 2000). Increased expression of this protein in plants enables more efficient water extraction from the soil (Mohammadi et al. 2012a). It was shown that the subunit B1, apart from its role as a regulatory subunit forming the catalytic center of ATPase, may influence the glucose signaling pathway, eventually affecting gene expression and plant growth (Cho et al. 2007; Zhao et al. 2009). Studies performed on transgenic tomatoes showed that plants producing large amounts of this subunit have a greater tolerance to drought and osmotic stress than wildtype plants ( $\mathrm{Hu}$ et al. 2012). Also wheat varieties with higher resistance to osmotic stress exhibit higher activity of V-type ATPase than susceptible cultivars (Zhao et al. 2009).

Another protein that increased in expression under osmotic stress was a putative phospholipase $\mathrm{D} \alpha 1$ precursor. Phospholipases are involved in the hydrolysis of 
phospholipids, in the processes of growth and ripening of plants. Some phospholipases have the ability to regulate cell volume and turgor under osmotic stress conditions (Chapman 1998). Phospholipase D is involved in the catabolism of phospholipids, such as phosphatidylcholine, phosphatidylethanolamine, phosphatidylglycerol (resulting in formation of signaling molecule-phosphatidic acid) (Bargmann and Munnik 2006). The enzymes appear to play a significant role in the control of seed germination, organ aging and trafficking (Chapman 1998; Bargmann and Munnik 2006). It was shown that phospholipase $D$ is involved in the ABA-dependent signal transduction induced by drought and salinity stress (Bargmann and Munnik 2006). Deficiency of phospholipase $\mathrm{D} \alpha$ reduces the plant's ability to adapt to drought stress (Sang et al. 2001). Other researchers also noted that in response to osmotic stress tolerant plants show an increased activity of phospholipase D (Munnik et al. 2000). Our experiment suggests that increase in phospholipase D under osmotic stress conditions results from increasing the synthesis of a precursor of the enzyme.

An interesting result was obtained when it comes to a hypothetical protein OsI_13043. The abundance of this protein under mild osmotic stress slightly increased in triticale roots, while in the roots treated with the moderate osmotic stress the protein showed a decreased expression. It can be assumed that this protein is involved in the response to water stress of low intensity.

The putative protein homologous to Hordeum vulgare subsp. vulgare protein of unknown function showed a stronger decrease in abundance in the triticale roots treated with mild than with moderate osmotic stress.

This study shows only a few proteins involved in triticale resistance to stress. The group of proteins which probably determine some adjustment of plant includes sHSP22, ribosomal protein S3, DEAD-box RNA helicase, USF protein, hypothetical protein TRIUR3_26221, peroxidase 66 and phospholipase $\mathrm{D} \alpha 1$ precursor.

On the basis of these results, it can be concluded that osmotic stress causes a number of metabolic disorders (expressed for example in cell wall elongation disturbances) and the impairment of defense protein accumulation (greater under moderate than under mild stress conditions), which indicates the high susceptibility of germinating triticale to adverse environmental conditions (especially to the osmotic stress of higher intensity).

We suggest that the overexpression of proteins such as $S$-adenosylmethionine synthetase, ascorbate peroxidase, glucan endo-1,3- $\beta$-glucosidase, $\beta$-glucosidase, $\mathrm{V}$-type ATPase B1 subunit, HSP70, yeiA protein or endoglucanase would probably provide a higher triticale tolerance to osmotic stress and should be considered as a target for genetic engineering of triticale varieties more resistant to the stress.

Author contribution Joanna Grębosz carried out most of the research and was the main author of this manuscript. Anna Badowiec provided all the technical support during the laboratory work and helped with manuscript preparation. Stanisław Weidner was the originator and responsible for experimental design. The manuscript was approved by all of the authors, who at the same time claim no conflict of interests.

Acknowledgments The authors wish to acknowledge the valuable suggestions provided by Professor Eric Davies during the writing of this article.

Open Access This article is distributed under the terms of the Creative Commons Attribution License which permits any use, distribution, and reproduction in any medium, provided the original author(s) and the source are credited.

\section{References}

Alvim FC, Carolino SMB, Cascardo JCM, Nunes CC, Martinez CA, Otoni WC, Fontes EPB (2001) Enhanced accumulation of BiP in transgenic plants confers tolerance to water stress. Plant Physiol 126:10420-11054. doi:10.1104/pp.126.3.1042

Amin M, Elias SM, Hossain A, Ferdousi A, Rahman MS, Tuteja N, Seraj ZI (2012) Over-expression of a DEAD-box helicase, PDH45, confers both seedling and reproductive stage salinity tolerance to rice (Oryza sativa L.). Mol Breed 30:345-354. doi:10.1007/s11032-011-9625-3

Badowiec A, Swigonska S, Weidner S (2013) Changes in the protein patterns in pea (Pisum sativum L.) roots under the influence of long- and short-term chilling stress and post-stress recovery. Plant Physiol Biochem 71:315-324. doi:10.1016/j.plaphy.2013. 08.001

Bargmann BO, Munnik T (2006) The role of phospholipase D in plant stress responses. Curr Opin Plant Biol 9:515-522. doi:10.1016/j. pbi.2006.07.011

Bevan M, Bansroft I, Bent E, Love K, Goodman H, Dean C et al (1998) Analysis of $1.9 \mathrm{Mb}$ of contiguous sequence from chromosome 4 of Arabidopsis thaliana. Nature 391:485-488. doi: $10.1038 / 35140$

Biswas GCG, Ransom C, Sticklen M (2006) Expression of biologically active Acidothermus cellulolyticus endoglucanase in transgenic maize plants. Plant Sci 171:617-623. doi:10.1016/j. plantsci.2006.06.004

Brosowska-Arendt W, Weidner S (2011) Effect of osmotic stress on the formation of a population of polysomes and their stability in pea (Pisum sativum L.) seeds. Acta Physiol Plant 33:1475-1482. doi:10.1007/s11738-010-0686-4

Budak H, Akpinar BA, Unver T, Turktas M (2013) Proteome changes in wild and modern wheat leaves upon drought stress by twodimensional electrophoresis and nanoLC-ESI-MS/MS. Plant Mol Biol. doi:10.1007/s11103-013-0024-5

Cairns JRK, Esen A (2010) B-glucosidases. Cell Mol Life Sci 67:3389-3405. doi:10.1007/s00018-010-0399-2

Chapman KD (1998) Phospholipase activity during plant growth and development and in response to environmental stress. Trends Plant Sci 3:419-425. doi:10.1016/S1360-1385(98)01326-0 
Cho YH, Yoo SD, Sheen J (2007) Glucose signaling through nuclear hexokinase1 complex in Arabidopsis. Plant Signal Behav 2:123-124. doi:10.1016/j.cell.2006.09.028

Chung E, Cho CW, Yun BH, Choi HK, So HA, Lee SW, Lee JH (2009) Molecular cloning and characterization of the soybean DEAD-box RNA helicase gene induced by low temperature and high salinity stress. Gene 443:91-99. doi:10.1016/j.gene.2009.05.005

Dani V, Simon WJ, Duranti M, Croy RRD (2005) Changes in the tobacco leaf apoplast proteome in response to salt stress. Proteomics 5:737-745. doi:10.1002/pmic.200401119

Dhugga KS, Tiwari SC, Ray PM (1997) A reversibly glycosylated polypeptide (RGP1) possibly involved in plant cell wall synthesis: purification, gene cloning, and trans-Golgi localization. Proc Natl Acad Sci USA 94:7679-7684. doi:10.1073/pnas. 94.14.7679

El Midaoui M, Serieys H, Griveau Y, Benbella M, Talouizte A, Bervillé A, Kaan F (2003) Effects of osmotic and water stresses on root and shoot morphology and seed yield in sunflower (Helianthus annuus L.) genotypes bred for Morocco or issued from introgression with $H$. argophyllus $\mathrm{T}$. \& G. and $H$. debilis Nutt. Helia 38:1-16. doi:10.2298/HEL0338001M

Espartero J, Pintor-Toro JA, Pardo JM (1994) Differential accumulation of $S$-adenosylmethionine synthetase transcripts in response to salt stress. Plant Mol Biol 25:217-227. doi:10.1007/ BF00023239

Gallardo K, Job C, Groot SPC, Puype M, Demol H, Vandekerckhove J, Job D (2002) Proteomics of Arabidopsis seeds germination: a comparative study of wild-type and gibberellin-deficient seeds. Plant Physiol 129:823-837. doi:10.1104/pp.002816

Ge P, Ma C, Wang S, Gao L, Li X, Guo G, Ma W, Yan Y (2012) Comparative proteomic analysis of grain development in two spring wheat varieties under drought stress. Anal Bioanal Chem 402:1297-1313. doi:10.1007/s00216-011-5532-z

Geilfus CM, Zörb C, Neuhaus C, Hansen T, Lüthen H, Mühling KH (2011) Differential transcript expression of wall-loosening candidates in leaves in maize cultivars differing in salt resistance. J Plant Growth Regul 30:387-395. doi:10.1007/ s00344-011-9201-4

Ghosh AK, Datta PK, Jacob ST (1997) The dual role of helix- loophelix-zipper protein USF in ribosomal gene transcription in vivo. Oncogene 14:589-594. doi:10.1038/sj.onc.1200866

Görg A, Weiss W, Dunn MJ (2004) Current two-dimensional electrophoresis technology for proteomics. Proteomics 12:3665-3685. doi:10.1002/pmic.200401031

Grillo MA, Colombatto S (2008) $S$-adenosylmethionine and its products. Amino acids 34:187-193. doi:10.1007/s00726-0070500-9

Hermosa R, Botella L, Keck E, Jimenéz JÁ, Montero-Barrientos M, Arbona V, Gómez-Cadenas A, Monte E, Nicolás C (2011) The overexpression in Arabidopsis thaliana of Trichoderma harzianum gene that modulates glucosidase activity, and enhances tolerance to salt and osmotic stresses. J Plant Physiol 168:1295-1302. doi:10.1016/j.jplph.2011.01.027

Hidese R, Mihara H, Kurihara T, Esaki N (2011) Escherichia coli dihydropyrimidine dehydrogenase is a novel NAD-dependent heterotetramer essential for the production of 5,6-dihydrouracil. J Bacteriol 193:989-993. doi:10.1128/JB.01178-10

Hochstenbach F, Klis FM, Ende H, Donselaar E, Peters PJ, Klausner RD (1998) Identification of a putative alpha-glucan synthase essential for cell wall construction and morphogenesis in fission yeast. Prot Natl Acad Sci USA 95:9161-9166. doi:10.1073/pnas. 95.16.9161

Hu DG, Wang SH, Luo H, Ma QJ, Yao YX, You CX, Hao YJ (2012) Overexpression of MdVHA-B, a V-ATPase gene from apple, confers tolerance to drought in transgenic tomato. Sci Hortic 145:94-101. doi:10.1016/j.scienta.2012.08.010
Huber DJ, Nevins DJ (1981) Partial purification of endo- and exo- $\beta$-Dglucanase enzymes from Zea mays L. seedlings and their involvement in cell-wall autohydrolysis. Planta 151:206-214. doi:10.1007/BF00395171

Jasińska Z, Kotecki A (2003) Szczegółowa uprawa roślin. AR, Wrocław, pp 164-165

Jiang Y, Deyholos MK (2006) Comprehensive transcriptional profiling of NaCl-stressed Arabidopsis roots reveals novel classes of responsive genes. BMC Plant Biol 6:25. doi:10.1186/1471-22296-25

Jiang Y, Yang B, Harris NS, Deyholos MK (2007) Proteomic comparative analysis of $\mathrm{NaCl}$ stress-responsive proteins in Arabidopsis roots. J Exp Bot 58:3591-3607. doi:10.1093/jxb/ erm207

Jost W, Baur A, Nick P, Reski R, Gorr G (2004) A large plant betatubulin family with minimal C-terminal variation but differences in expression. Gene 340:151-160. doi:10.1016/j.gene.2004.06. 009

Kim HD, Lee JY, Kim J (2005) Erk phosphorylates threonine 42 residue of ribosomal protein S3. Biochem Biophys Res Commun 333:110-115. doi:10.1016/j.bbrc.2005.05.079

Kok-Jacon GA, Ji Q, Vincken JP, Visser RGF (2003) Towards a more versatile $\alpha$-glucan biosynthesis in plants. J Plant Physiol 160:765-777. doi:10.1078/0176-1617-01028

Kosová K, Vitámvás P, Prášil IT, Renaut J (2011) Plant proteome changes under abiotic stress-contribution of proteomics studies to understanding plant stress response. J Proteomics 74:1301-1322. doi:10.1016/j.jprot.2011.02.006

Koussevitzky S, Suzuki N, Huntington S, Armijo L, Sha W, Cortes D, Shulaev V, Mittler R (2008) Ascorbate peroxidase 1 plays a key role in the response of Arabidopsis thaliana to stress combination. J Biol Chem 283:34197-34203. doi:10.1074/jbc. M806337200

Laemmli UK (1970) Cleavage of structural proteins during the assembly of the head of bacteriophage T4. Nature 227:680-685. doi:10.1038/227680a0

Leah R, Kigel J, Svendsen I, Mundy J (1995) Biochemical and molecular characterization of a barley seed $\beta$-glucosidase. J Biol Chem 270:15789-15797. doi:10.1074/jbc.270.26.15789

Legocka J, Kluk A (2005) Effect of salt and osmotic stress on changes in polyamine content and arginine decarboxylase activity in Lupinus luteus seedlings. J Plant Physiol 162:662-668. doi:10. 1016/j.jplph.2004.08.009

Libusová L, Sulimenko T, Janisch R, Hozák P, Dráber P (2005) Distinct localization of a beta-tubulin epitope in the Tetrahymena thermophila and Paramecium caudatum cortex. Protoplasma 225:157-167. doi:10.1007/s00709-005-0097-3

Liu B (2011) The plant cytoskeleton. Springer, New York, pp 3-4 7

Ma T, Chen R, Yu R, Zeng H, Zhang D (2009) Differential global genomic changes in rice root in response to low-, middle- and high-osmotic stresses. Acta Physiol Plant 31:773-785. doi:10. 1007/s11738-009-0291-6

Mansour MMF (2000) Nitrogen containing compounds and adaptation of plants to salinity stress. Biol Plant 43:491-500. doi:10. 1023/A:1002873531707

Mohammadi M, Kav NNV, Deyholos MK (2007) Transcriptional profiling of hexaploid wheat (Triticum aestivum L.) roots identifies novel, dehydration-responsives genes. Plant Cell Environ 30:630-645. doi:10.1111/j.1365-3040.2007.01645.x

Mohammadi PP, Moieni A, Hiraga S, Komatsu S (2012a) Organspecific proteomic analysis of drought-stressed soybean seedlings. J Proteomics 75:1906-1923. doi:10.1016/j.jprot.2011.12.041

Mohammadi PP, Moieni A, Komatsu S (2012b) Comparative proteome analysis of drought-sensitive and drought-tolerant rapeseed roots and their hybrid $\mathrm{F} 1$ line under drought stress. Amino Acids. doi:10.1007/s00726-012-1299-6 
Munnik T, Meijer HJG (2001) Osmotic stress activates distinct lipid and MAPK signalling pathways in plants. FEBS Lett 498:172-178. doi:10.1016/S0014-5793(01)02492-9

Munnik T, Meijer HJG, Riet B, Hirt H, Frank W, Bartels D, Musgrave A (2000) Hyperosmotic stress stimulates phospholipase D activity and elevates the levels of phosphatidic acid and diacylglycerol pyrophosphate. Plant J 22:147-154. doi:10.1046/j.1365-313x.2000.00725.x

Nakamura T, Muramoto Y, Yokota S, Ueda A, Takabe T (2004) Structural and transcriptional characterization of salt-responsive gene encoding putative ATP-dependent RNA helicase in barley. Plant Sci 167:63-70. doi:10.1016/j.plantsci.2004.03.001

Neuhoff A, Arold N, Taube D, Ehrhardt W (1988) Improved staining of proteins in polyacrylamide gels including isoelectric focusing gels with clear background at nanogram sensitivity using Coomassie Brilliant Blue G-250 and R-250. Electrophoresis 9:255-262. doi:10.1002/elps.1150090603

O'Farrel PH (1975) High resolution two-dimensional electrophoresis of proteins. J Biol Chem 10:4007-4021

Oliveira L (1982) The development of chloroplasts in root meristematic tissue of Secale cereale L. seedlings. New Phytol 91:263-275. doi:10.1111/j.1469-8137.1982.tb03311.x

Passardi F, Cosio C, Penel C, Dunand C (2005) Peroxidases have more functions than a Swiss army knife. Plant Cell Rep 24:255-265. doi:10.1007/s00299-005-0972-6

Quados A (2010) Effect of salt stress on plant growth and matabolism of bean plant Vicia faba (L.). J Saudi Soc Agric Sci 10:7-15. doi:10.1016/j.jssas.2010.06.002

Qyang Y, Luo X, Lu T, Ismail PM, Krylov D, Vinson C, Sawadogo M (1999) Cell-type dependent activity of the ubiquitous transcription factor USF in cellular proliferation and transcriptional activation. Mol Cell Biol 19:1508-1517

Rakha A, Åman P, Andersson R (2011) Dietary fiber in triticale grain: variation in content, composition and molecular weight distribution of extractable components. J Cereal Sci 54:324-331. doi:10.1016/j.jcs.2011.06.010

Rao KVM, Raghavendra AS, Janardhan Reddy K (2006) Physiology and molecular biology of stress tolerance in plants. Springer, Dordrecht, $\mathrm{p} 41$

Reddy AR, Chaitanya KV, Vivekanandan M (2004) Drought-induced responses of photosynthesis and antioxidant metabolism in higher plants. J Plant Physiol 161:1189-1202. doi:10.1016/j. jplph.2004.01.013

Salekdeh GH, Siopongco J, Wade LJ, Ghareyazie B, Bennett J (2002) A proteomic approach to analyzing drought- and salt-responsiveness in rice. Field Crop Res 76:199-219. doi:10.1016/S03784290(02)00040-0

Sang Y, Zheng S, Li W, Huang B, Wang X (2001) Regulation of plant water loss by manipulating the expression phospholipase $\mathrm{D} \alpha$. Plant J 28:135-144. doi:10.1046/j.1365-313X.2001.01138.x

Sarkar NK, Kim YK, Grover A (2009) Rice sHsp genes: genomic organization and expression profiling under stress and development. BMC Genomics 10:393. doi:10.1186/1471-2164-10-393

Shevchenko A, Wilm M, Vorm O, Mann M (1996) Mass spectrometric sequencing of proteins from silver stained polyacrylamide gels. Anal Chem 68:850-858. doi:10.1021/ac950914h

Slama I, Ghnaya T, Hessini K, Messedi D, Savouré A, Abdelly C (2007) Comparative study of the effects of mannitol and PEG osmotic stress on growth and solute accumulation in Sesuvium portulacastrum. Environ Exp Bot 61:10-17. doi:10.1016/j. envexpbot.2007.02.004

Sobhanian H, Aghaei K, Komatsu S (2011) Changes in plant proteome resulting from salt stress: toward the creation of salttolerant crops? J Proteomics 74:1323-1337. doi:10.1016/j.jprot. 2011.03.018

Song Y, Zhang C, Ge W, Zhang Y, Burlingame AL, Guo Y (2011) Identification of $\mathrm{NaCl}$ stress-responsive apoplastic proteins in rice shoot stems by 2D-DIGE. J Proteomics 74:1045-1067. doi:10.1016/j.jprot.2011.03.009

Swigonska S, Weidner S (2013) Proteomic analysis of response to longterm continuous stress in roots of germinating soybean seeds. J Plant Physiol 170:470-479. doi:10.1016/j.jplph.2012.11.020

Tamura T, Hara K, Yamaguchi Y, Koizumi N, Sano H (2003) Osmotic stress tolerance of transgenic tobacco expressing a gene encoding a membrane-located receptor-like protein from tobacco plants. Plant Physiol 131:454-462. doi:10.1104/pp.102.011007

Timperio AM, Egidi MG, Zolla L (2008) Proteomics applied on plant abiotic stresses: role of heat shock proteins (HSP). J Proteomics 71:391-411. doi:10.1016/j.jprot.2008.07.005

Tohver M, Kann A, Täht R, Mihhalevski H, Hakman J (2005) Quality of triticale cultivars suitable for growing and bread-making in northern conditions. Food Chem 89:125-132. doi:10.1016/j. foodchem.2004.01.079

Toorchi M, Yukawa K, Nouri MZ, Komatsu S (2009) Proteomics approach for identifying osmotic-stress-related proteins in soybean roots. Peptides 30:2108-2117. doi:10.1016/j.peptides.2009.09.006

Vashisht AA, Tuteja N (2006) Stress- responsive DEAD-box helicases: a new pathway to engineer plant stress tolerance. J Photochem Photobiol B biol 84:150-160. doi:10.1016/j. jphotobiol.2006.02.010

Verslues PE, Ober ES, Sharp RE (1998) Root growth and oxygen relations at low water potentials. Impact of oxygen availability in polyethylene glycol solutions. Plant Physiol 116:1403-1412. doi:10.1104/pp.116.4.1403

Wan F, Anderson DE, Barnitz RA, Snow A, Bidere N, Zheng L, Hegde V, Lam LT, Staudt LM, Levens D, Deutsch WA, Lenardo MJ (2007) Ribosomal protein S3: a KH domain subunit in NF$\kappa \mathrm{B}$ complexes that mediates selective gene regulation. Cell 131:927-939. doi:10.1016/j.cell.2007.10.009

Wang BS, Ratajczak R, Zhang JH (2000) Activity, amount and subunit composition of vacuolar-type $\mathrm{H}^{+}$-ATPase and $\mathrm{H}^{+}$-PPase in wheat roots under severe $\mathrm{NaCl}$ stress. J Plant Physiol 157:109-116. doi:10.1016/S0176-1617(00)80143-1

Wang P, Liu H, Hua H, Wang L, Song CP (2011) A vacuole localized $\beta$-glucosidase contributes to drought tolerance in Arabidopsis. Chin Sci Bull 56:3538-3546. doi:10.1007/s11434-011-4802-7

Wi SJ, Kim WT, Park KY (2006) Overexpression of carnation $S$ adenosylmethionine decarboxylase gene generates a broad-spectrum tolerance to abiotic stresses in transgenic tobacco plants. Plant Cell Rep 25:1111-1121. doi:10.1007/s00299-006-0160-3

Xiong L, Zhu JK (2002) Molecular and genetic aspects of plant responses to osmotic stress. Plant Cell Environ 25:131-139. doi:10.1046/j.1365-3040.2002.00782.x

Xu C, Huang B (2010) Differential proteomic responses to water stress induced by PEG in two creeping bentgrass cultivars differing in stress tolerance. J Plant Physiol 167:1477-1485. doi:10.1016/j.jplph.2010.05.006

Xu C, Sibicky T, Huang B (2010) Protein profile analysis of saltresponsive proteins in leaves and roots in two cultivars of creeping bentgrass differing in salinity tolerance. Plant Cell Rep 29:595-615. doi:10.1007/s00299-010-0847-3

Yan S, Tang Z, Su W, Sun W (2005) Proteomic analysis of salt stressresponsive proteins in rice root. Proteomics 5:235-244. doi:10. 1002/pmic.200400853

Yokoi S, Bressan RA, Hasegawa PM (2002) Salt stress tolerance of plants. JIRCAS Work Rep, vol 1, pp 25-33

Zhao Q, Zhao YJ, Zhao BC, Ge RC, Li M, Shen YZ, Huang ZJ (2009) Cloning and functional analysis of wheat $\mathrm{V}-\mathrm{H}^{+}$-ATPase subunit genes. Plant Mol Biol 69:33-46. doi:10.1007/s11103-008-9403-8

Zrenner R, Riegel H, Marquard CR, Lange PR, Geserick C, Bartosz CE, Chen CT, Slocum RD (2009) A functional analysis of the pyrimidine catabolic pathway in Arabidopsis. New Phytol 183:117-132. doi:10.1111/j.1469-8137.2009.02843.x 